Louisiana State University

LSU Digital Commons

Faculty Publications

Department of Oceanography \& Coastal

Sciences

$1-2016$

\title{
Size-Dependent Top-Down Control On Phytoplankton Growth By Microzooplankton In Eutrophic Lakes
}

Wai Hing Wong

Nancy N. Rabalais

nrabalais@lumcon.edu

R. Eugene Turner

euturne@lsu.edu

Follow this and additional works at: https://digitalcommons.Isu.edu/oceanography_coastal_pubs

Part of the Oceanography Commons

\section{Recommended Citation}

Wong, W. H., Rabalais, N. N., \& Turner, R. (2016). Size-Dependent Top-Down Control On Phytoplankton Growth By Microzooplankton In Eutrophic Lakes. https://doi.org/DOI: 10.1007/s10750-015-2365-3

This Article is brought to you for free and open access by the Department of Oceanography \& Coastal Sciences at LSU Digital Commons. It has been accepted for inclusion in Faculty Publications by an authorized administrator of LSU Digital Commons. For more information, please contact ir@lsu.edu. 
See discussions, stats, and author profiles for this publication at: https://www.researchgate.net/publication/285962919

\section{Size-dependent top-down control on phytoplankton growth by microzooplankton in eutrophic lakes}

Article in Hydrobiologia · January 2016

DOI: 10.1007/s10750-015-2365-3

\section{CITATIONS}

10

3 authors, including:

N. N. Rabalais

Louisiana State University

247 PUBLICATIONS 21,850 CITATIONS

SEE PROFILE
READS

85

Robert Eugene Turner

Louisiana State University

303 PUBLICATIONS 23,447 CITATIONS

SEE PROFILE

Some of the authors of this publication are also working on these related projects:

Project Benthic Infauna in the northern Gulf of Mexico View project

Project Microphytobenthos in the northern Gulf of Mexico View project 
Size-dependent top-down control on phytoplankton growth by microzooplankton in eutrophic lakes

\section{Wai Hing Wong, Nancy N. Rabalais \& R. Eugene Turner}

Hydrobiologia

The International Journal of Aquatic Sciences

ISSN 0018-8158

Hydrobiologia

DOI 10.1007/s10750-015-2365-3

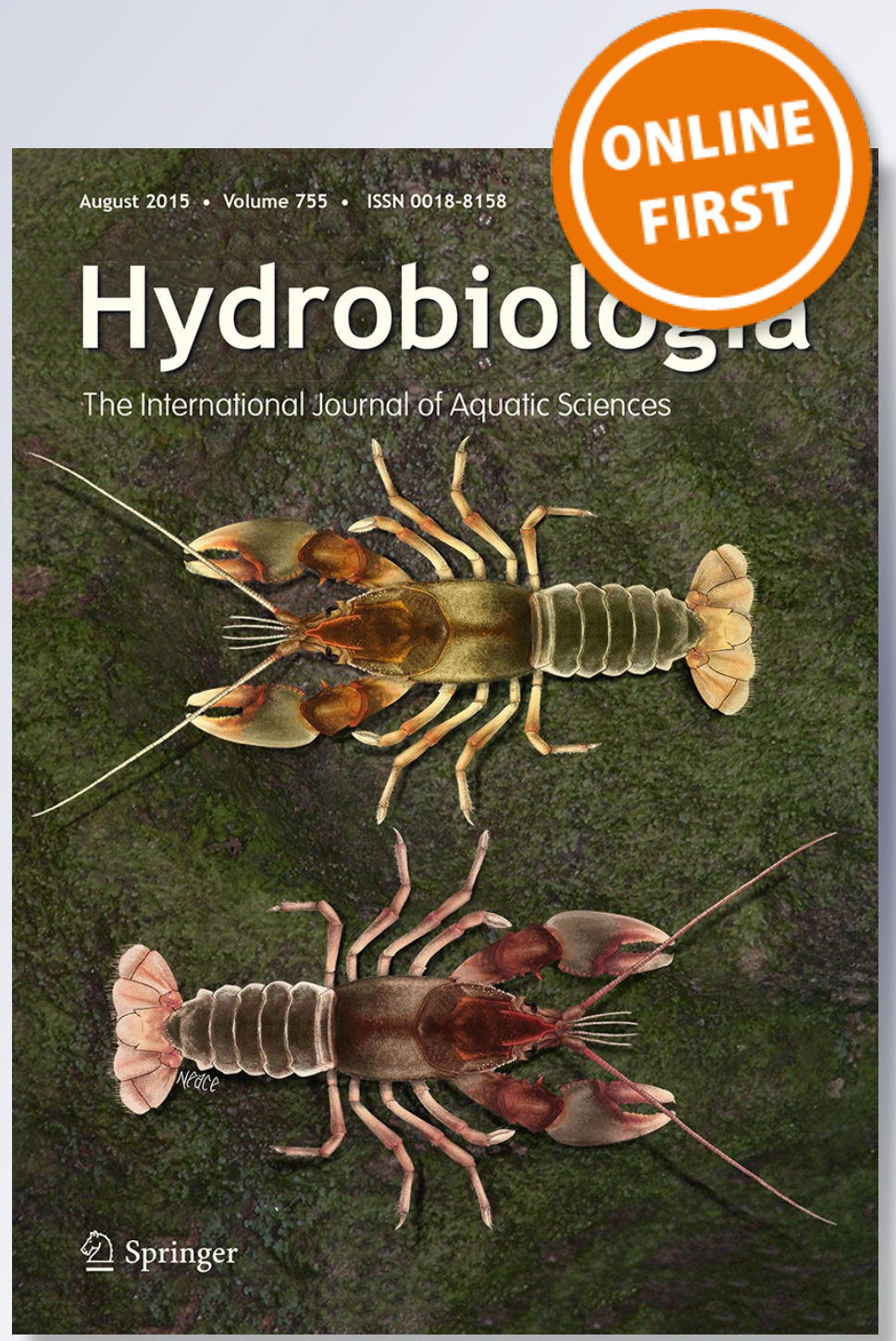

Springer 
Your article is protected by copyright and all rights are held exclusively by Springer International Publishing Switzerland. This eoffprint is for personal use only and shall not be self-archived in electronic repositories. If you wish to self-archive your article, please use the accepted manuscript version for posting on your own website. You may further deposit the accepted manuscript version in any repository, provided it is only made publicly available 12 months after official publication or later and provided acknowledgement is given to the original source of publication and a link is inserted to the published article on Springer's website. The link must be accompanied by the following text: "The final publication is available at link.springer.com". 


\title{
Size-dependent top-down control on phytoplankton growth by microzooplankton in eutrophic lakes
}

\author{
Wai Hing Wong • Nancy N. Rabalais • \\ R. Eugene Turner
}

Received: 1 September 2014/Revised: 2 June 2015/Accepted: 8 June 2015

(C) Springer International Publishing Switzerland 2015

\begin{abstract}
We hypothesized that the grazing on phytoplankton by the microzooplankton community is size-dependent and, therefore, the top-down control on phytoplankton by microzooplankton community could be one possible mechanism explaining why small phytoplankton become less abundant than large phytoplankton in eutrophic waters. We tested this hypothesis using the dilution method to measure microzooplankton grazing rates and phytoplankton growth rates in the eutrophic waters of the Barataria estuary, southeastern Louisiana. Microzooplankton grazing rates on the slower growing, small phytoplankton $(<5 \mu \mathrm{m})$ were higher than on the large phytoplankton $(>20 \mu \mathrm{m})$ which had relatively faster growth rates. The proportional loss of the small,
\end{abstract}

Handling editor: Zhengwen Liu

W. H. Wong $(\bowtie)$

Division of Watershed Management, Massachusetts Department of Environmental Protection, 8 New Bond Street, Worcester, MA 01606, USA

e-mail: david.w.wong@state.ma.us

N. N. Rabalais

Louisiana Universities Marine Consortium, 8124

Highway 56, Chauvin, LA 70344, USA

e-mail: nrabalais@1umcon.edu

\section{R. E. Turner}

Department of Oceanography and Coastal Sciences, Louisiana State University, Baton Rouge, LA 70803, USA

e-mail: euturne@1su.edu medium, large phytoplankton, and total phytoplankton community by microzooplankton grazing was 44,53 , 0 , and $29 \%$, respectively. The relative weakness of top-down grazing control on large phytoplankton by microzooplankton, and the relatively fast growth of large phytoplankton, may be why the average size of phytoplankton, whether isolated cells or colonies, tend to increase in these eutrophic waters and elsewhere.

Keywords Microzooplankton · Grazing · Phytoplankton growth · Eutrophication

\section{Introduction}

Although small phytoplankton, such as picoplankton, may be quantitatively important in some productive waters (Carrick \& Schelske, 1997), many studies have demonstrated that phytoplankton size structure shifts from smaller cells to larger-sized phytoplankton and/ or colonies when waters become eutrophic (Watson \& Kalff, 1981; Harris, 1986; Duarte et al., 1990; Chisholm, 1992; Duarte \& Canfield, 1992; Gin et al., 2000). The results from experiments suggest that there is a physiological basis for this pattern (Legendre et al., 1993; Tamigneaux et al., 1999). Cermeño et al. (2005), for example, demonstrated that both lightsaturated, chlorophyll-specific photosynthesis, and the maximum photosystem (II) photochemical efficiency, were significantly higher in the $>20 \mu \mathrm{m}$ size class than in smaller size classes $(<5$, and 5-20 $\mu \mathrm{m})$. This result 
may explain why large phytoplankton become dominant in eutrophic waters (Cermeño et al., 2005), but more work remains to be done (Raven, 1998). For example, the relationships between grazer and prey may also be an important influence on the size structure of phytoplankton communities (Thatcher et al., 1993; Haga et al., 1995). Microzooplankton grazers $(<200 \mu \mathrm{m})$ can quickly respond to changes in the abundance of their phytoplankton prey, and thereby contribute to the dynamic equilibrium in the biomass of each prey (Fenchel, 1982; Sherr \& Sherr, 1984; Goldman \& Caron, 1985). It is recognized that the active grazing by microzooplankton in marine systems is a common phenomenon that plays a more crucial role than mesozooplankton $(>200 \mu \mathrm{m})$ grazing in structuring the whole phytoplankton community, even though phytoplankton are the most important dietary component of mesozooplankton (Strom et al., 2001; Calbet \& Landry, 2004; Liu et al., 2014). Meanwhile, based on estimation of metabolic rates (i.e., feeding and growth) of individual zooplankton species, it has been found that the grazing efficiency of different groups (i.e., nano-, micro-, and mesozooplankton) is different (Hansen et al., 1997). However, the size selectivity data are collected based on individual species under laboratory conditions (Hansen et al., 1997 and references therein). In the present study, we hypothesized that the grazing on phytoplankton by the microzooplankton community is sizedependent and, therefore, the top-down control on phytoplankton by microzooplankton community could also be a possible mechanism explaining why small phytoplankton become less abundant than large phytoplankton in eutrophic/hypereutrophic waters. We tested this hypothesis by making seasonal estimates of microzooplankton grazing rates and phytoplankton growth rates in three eutrophic freshwater and brackish water lakes in southeastern Louisiana, USA.

\section{Materials and methods}

\section{Sampling stations}

We collected water over four seasons for plankton samples from three shallow $(<2.5 \mathrm{~m})$ coastal lakes (Lake Cataouatche, Lake Salvador, and Lac des Allemands, Fig. 1) in the upper Barataria estuary of southeastern Louisiana (Table 1). The locations for water collection were $29^{\circ} 49.730 \mathrm{~N}$ and $90^{\circ} 11.000 \mathrm{~W}$ in Lake Cataouatche, $29^{\circ} 45.990 \mathrm{~N}$ and $90^{\circ} 10.990 \mathrm{~W}$ in Lake Salvador, and $29^{\circ} 53.580 \mathrm{~N}$ and $90^{\circ} 34.750 \mathrm{~W}$ in Lac des Allemands (Fig. 1). The brackish lakes Salvador and Cataouatche, whose salinities are occasionally about 7.6 psu (Ren et al., 2009), are influenced by microtidal exchange with the lower Barataria Bay and Gulf of Mexico (i.e., the tidal change is not as significant as the typical spring and neap tides). These lakes are intermittently influenced by flow from the U.S. Army Corps of Engineers Mississippi River water diversion at Davis Pond that enters Lake Cataouatche on the north, and that flows into Lake Salvador to the south. Lac des Allemands is a freshwater lake with no influence from the Mississippi River diversion, and has chlorophyll $a$ concentrations that occasionally rise above $200 \mu \mathrm{g} \mathrm{l}^{-1}$ (Table 2). Lake water salinity, dissolved oxygen, and temperature were measured with a Hydrolab $\mathrm{H}_{2} \mathrm{O}$ Surveyor 3 (Hydrolab-Hach Company, Loveland, Colorado; Table 1). A minimum of one hundred $L$ of water from each lake was collected at $20-30 \mathrm{~cm}$ below the water's surface at 16:30 h, carefully poured into $75 \mathrm{l}$ carboys so as not to damage the delicate microzooplankton, and transported to a laboratory by 18:30 h.

\section{Microzooplankton sampling and counting}

We collected zooplankton samples with a $0.34 \mathrm{~m}$ diameter $\times 2.5 \mathrm{~m}$ long, $37 \mu \mathrm{m}$ mesh plankton net towed $5 \mathrm{~cm}$ below the water's surface for 30-90 s (the tow length depended on the water turbidity) (Pagano \& Saintjean, 1989; Liu \& Dagg, 2003). The volume of water filtered through the net was measured with a calibrated General Oceanics flowmeter mounted in the net opening. The towing distance and volume filtered were calculated based on the equations provided by General Oceanics, where

$$
\begin{aligned}
\text { Distance }= & (\text { No. of rotations of flowmeter }) \\
& \times \text { Rotor constant } / 999,999
\end{aligned}
$$

and,

Water volume $=$ Distance $\times \pi \times(\text { radius of net })^{2}$.

Two aliquots of plankton net-filtered water samples were collected at four sites from each of the three lakes in October 2003, January to February 2004, March to 


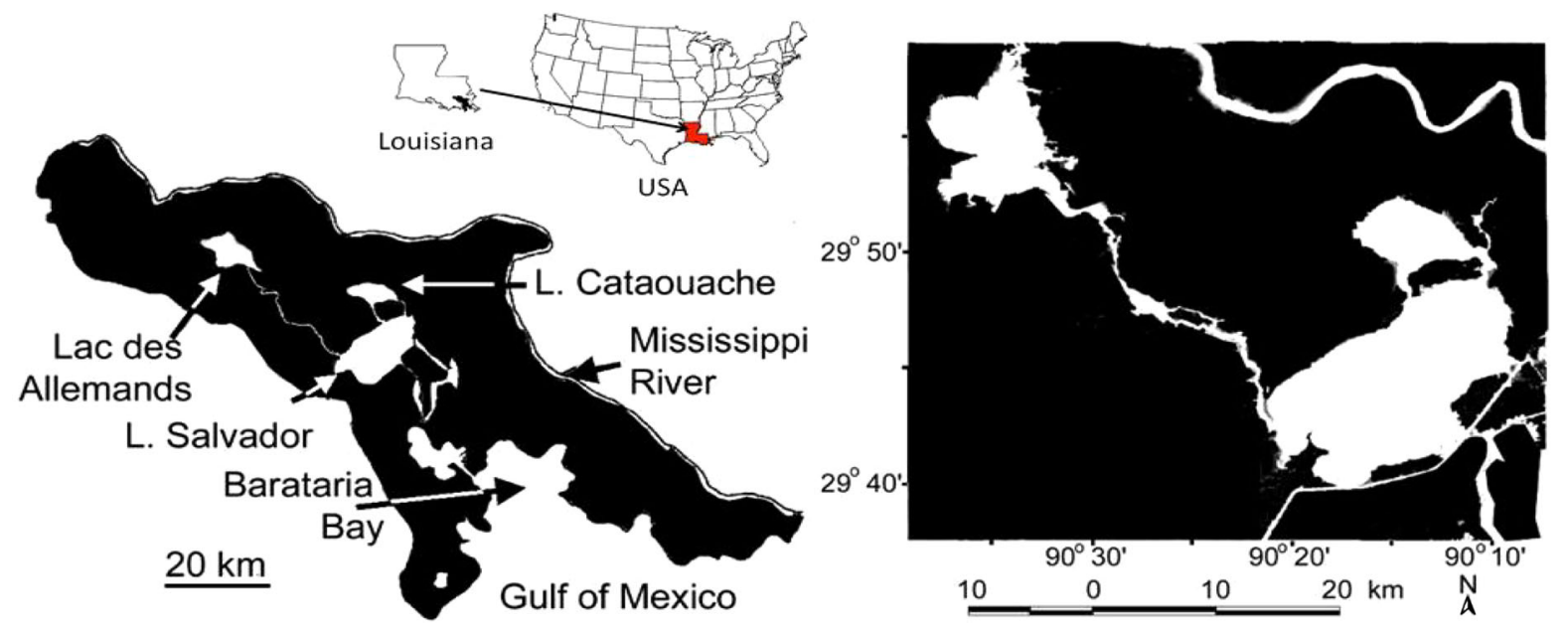

Fig. 1 Locations of Lake Cataouatche, Lake Salvador, and Lac des Allemands in the upper Barataria estuary

Table 1 Surface water characteristics of the lakes and experimental incubators for the twelve experiments

\begin{tabular}{|c|c|c|c|c|c|}
\hline Season/date & Water body & Lake temperature $\left({ }^{\circ} \mathrm{C}\right)$ & $\mathrm{DO}\left(\mathrm{mg}^{-1}\right)$ & Salinity (psu) & Incubator temperature $\left({ }^{\circ} \mathrm{C}\right)$ \\
\hline \multicolumn{6}{|l|}{ Autumn } \\
\hline $10 / 13 / 2003$ & Lake Cataouatche & 25.4 & 9.0 & 0.7 & N/A \\
\hline $10 / 21 / 2003$ & Lake Salvador & N/A & N/A & N/A & 23.0 \\
\hline $10 / 28 / 2003$ & Lac des Allemands & 21.7 & 9.8 & 0.1 & 21.5 \\
\hline \multicolumn{6}{|l|}{ Winter } \\
\hline $01 / 12 / 2004$ & Lake Cataouatche & 11.8 & 14.6 & 0.4 & 11.5 \\
\hline $01 / 20 / 2004$ & Lake Salvador & 12.5 & 10.5 & 0.7 & 12.0 \\
\hline $02 / 03 / 2004$ & Lac des Allemands & 12.0 & 11.9 & 0.1 & 12.0 \\
\hline \multicolumn{6}{|l|}{ Spring } \\
\hline $03 / 30 / 2004$ & Lake Cataouatche & 23.3 & 9.6 & 0.3 & 22.0 \\
\hline $04 / 05 / 2004$ & Lake Salvador & 21.7 & 11.0 & 0.3 & 21.0 \\
\hline $04 / 12 / 2004$ & Lac des Allemands & 21.0 & 7.8 & 0.1 & 20.0 \\
\hline \multicolumn{6}{|l|}{ Summer } \\
\hline $06 / 28 / 2004$ & Lake Cataouatche & N/A & N/A & N/A & 31.0 \\
\hline $07 / 05 / 2004$ & Lake Salvador & 31.2 & 7.8 & 0.1 & 31.0 \\
\hline $07 / 11 / 2004$ & Lac des Allemands & 29.7 & 7.5 & 0.2 & 30.5 \\
\hline
\end{tabular}

N/A no data available

April 2004, and June to July 2004. One aliquot was preserved with formalin (final concentration $2 \%$ ) to quantify the density of small rotifers $(<202 \mu \mathrm{m})$ (Garza-Mourino et al., 2005). The other aliquot was preserved with Lugol's (final concentration 3\%) and used to enumerate ciliates (Bulit et al., 2003). A $10 \mathrm{ml}$ subsample was placed in an Utermöhl sedimentation chamber to settle for $8-12 \mathrm{~h}$ before being counted with an inverted microscope (Nikon-TMD 300) at $\times 200$ or 400 magnification. The abundance of microzooplankton was only estimated as the sum of the density of all small rotifers + ciliates $(<202 \mu \mathrm{m})$, because smaller microzooplankton such as heterotrophic dinoflagellates and small ciliates $(<37 \mu \mathrm{m})$ were not counted, and because nauplii (usually $>202 \mu \mathrm{m}$ ), large rotifers, and mesozooplankton were removed. Water sample 
Table 2 Chlorophyll $a$ content $\left(\mu \mathrm{g}^{-1}\right)$ and microzooplankton density (individual $1^{-1}$; mean \pm 1 $\mathrm{SD})$ in the lakes by season

\begin{tabular}{llll}
\hline Season & Lake Cataouatche & Lake Salvador & Lac des Allemands \\
\hline Chlorophyll $a$ & & & \\
Autumn 2003 & $7.41 \pm 0.14$ & $3.56 \pm 0.07$ & $18.13 \pm 0.28$ \\
Winter 2004 & $47.43 \pm 5.27$ & $7.61 \pm 0.42$ & $184.92 \pm 2.47$ \\
Spring 2004 & $6.76 \pm 0.00$ & $24.23 \pm 1.41$ & $17.12 \pm 0.21$ \\
Summer 2004 & $8.92 \pm 0.19$ & $6.76 \pm 0.11$ & $26.91 \pm 0.28$ \\
Average & 17.63 & 10.54 & 61.77 \\
Microzooplankton & & & \\
Autumn 2003 & $2032.6 \pm 743.1$ & $1158.7 \pm 690.8$ & $5187.5 \pm 1553.9$ \\
Winter 2004 & $2188.2 \pm 272.0$ & $2522.9 \pm 496.8$ & $4125.4 \pm 1438.2$ \\
Spring 2004 & $4248.5 \pm 1495.0$ & $2340.0 \pm 658.6$ & $3829.2 \pm 735.6$ \\
Summer 2004 & $974.7 \pm 282.5$ & $2352.0 \pm 519.8$ & $4877.3 \pm 829.5$ \\
Average & 2361.0 & 2093.4 & 4504.9 \\
\hline
\end{tabular}

were screened with a $202 \mu \mathrm{m}$ mesh before being used in the microzooplankton grazing experiments and the microzooplankton density was determined. The samples were diluted before being placed in Utermöhl sedimentation chambers if the microzooplankton density was too high to count.

\section{Microzooplankton grazing experiments}

We determined microzooplankton grazing on phytoplankton and phytoplankton growth by using the dilution method (Landry \& Hassett, 1982) in twelve microzooplankton grazing experiments conducted from Autumn 2003 to Summer 2004. All experimental bottles, tubing and other containers were washed with $10 \% \mathrm{HCl}$ and rinsed twice with distilled and de-ionized water before use. Water samples were slowly and carefully screened with a $202 \mu \mathrm{m}$ mesh net under gravity to remove mesozooplankton. The dilution medium was prepared from screened water $(401)$ that was pre-filtered with a peristaltic pump (Millipore, MA, USA) through a GF/F filter $(0.5 \mu \mathrm{m})$, and then gravityfiltered with a $0.2 \mu \mathrm{m}$ in-line AcroPak $^{\mathrm{TM}} 500$ filter capsule (Pall Corporation, Ann Harbor, Michigan). Screened water $(202 \mu \mathrm{m})$ was diluted with the dilution medium and put into plastic containers to create the following concentration of the original unfiltered water: $6.25,12.5,25,50$, and $100 \%$. Inorganic nutrients- $\mathrm{N}$ $\left(\mathrm{NO}_{3}{ }^{-}\right), \mathrm{P}\left(\mathrm{H}_{2} \mathrm{PO}_{4}{ }^{-}\right)$, and $\mathrm{Si}\left(\mathrm{SiO}_{4}^{-2}\right)$ at Redfield Ratios $($ molar ratio $=\mathrm{N}: \mathrm{P}: \mathrm{Si}:: 16: 1: 16)$ — were added to each container in sufficient amount to support doubling the initial chlorophyll $a$ concentration in 2 days (Table 3 in Ren et al., 2009), so that no nutrient deficiencies would occur during incubations. A sixth container was filled with $100 \%$ lake water that had no nutrient additions and was screened through a $202 \mu \mathrm{m}$ mesh. The four experimental replicates were then dispensed into narrow-mouth 21 polycarbonate (NALGENE) bottles, sealed without air bubbles, and randomly placed in a large outdoor Plexiglas incubator (length $\times$ width $\times$ depth $=1.45 \times 0.76 \times 0.38 \mathrm{~m}^{3}$ ) set up on the Louisiana Universities Marine Consortium dock. Near-surface marina waters were pumped through this incubator to maintain ambient temperature. There were no differences in water temperature between the incubator and the lakes (Table 1, paired $t$ test, $P>0.05, n=9$ ). One layer of neutral screen was applied to reduce the light level to that at $0.5 \mathrm{~m}$ below the water surface. The flowing water maintained the 21 containers in continuous suspension, but they were also physically and randomly relocated every $4 \mathrm{~h}$ during the $24 \mathrm{~h}$ incubations.

Three to $250 \mathrm{ml}$ of each dilution were filtered at 0 and $24 \mathrm{~h}$ using a $20 \mu \mathrm{m}$ polycarbonate filter (Osmonics), a $5 \mu \mathrm{m}$ polycarbonate filter (Whatman), and a $\mathrm{GF} / \mathrm{F}$ glass fiber filter (Whatman, $0.7 \mu \mathrm{m}$ ). The volume filtered depended on the chlorophyll $a$ concentration and the size of the filter paper being used. The filters were extracted with DMSO in a 40:60 mixture with $90 \%$ acetone for $10-12 \mathrm{~h}$, and the fluorescence of the extract was measured with a Turner Design fluorometer (10-AU, Sunnyvale, California) before and after acidification. The chlorophyll $a$ concentrations from the three size-fractionated phytoplankton $(<5,5-20$, and $>20 \mu \mathrm{m})$ were calculated. Total content of chlorophyll $a$ of two raw water 
samples from each lake in each season was also quantified (Table 2).

We followed established protocols to calculate phytoplankton growth rates and zooplankton grazing rates on phytoplankton. Nutrient-amended dilution treatments were used to calculate zooplankton grazing rates, and treatments without nutrient addition were used to estimate phytoplankton growth rate (Landry et al., 1998; Calbet \& Landry, 2004). The phytoplankton apparent growth rate $\left(\mathrm{k} \mathrm{day}^{-1}\right)$ was calculated as the variation of chlorophyll $a$ concentration during the $24 \mathrm{~h}$ incubation, $k=\ln \left(P_{t} / P_{0}\right)$, where $P_{0}\left(\mu \mathrm{g} 1^{-1}\right)$ is the initial chlorophyll $a$ content, and $P_{t}\left(\mu \mathrm{g} l^{-1}\right)$ is the chlorophyll $a$ content at the end of the $24 \mathrm{~h}$ incubation. The phytoplankton grazing mortality rate $\left(\mathrm{m}: \mathrm{day}^{-1}\right)$ was calculated by linear regression of the apparent growth rate $\left(k_{n}\right)$ versus the dilution factor $(D$ : fraction of undiluted water) from the nutrient-enhanced dilution treatments. The instantaneous growth rate $\left(\mu_{0}\right.$ day $^{-1}$ ) without nutrient addition was estimated as:

$\mu_{0}=k_{0}+m$,

where $k_{0}$ is the apparent growth rate of phytoplankton in the treatments without nutrient additions. When saturation grazing occurred (Gallegos, 1989), $k_{n}$ from greater than half dilution treatments $(D<0.5)$ were used in the linear regression to obtain $\mu_{n}$, the phytoplankton instantaneous growth rate under the condition of nutrient enrichment (Redden et al., 2002). Microzooplankton grazing mortality rate $(m)$ was therefore calculated as

$m=\mu_{n}-k_{n}$

(Liu \& Dagg, 2003). Some negative estimates are expected because of photoacclimation responses of phytoplankton to experimental incubation conditions or because day-to-day variations in light levels might produce offsetting positive and negative errors in the growth rate estimates (Calbet \& Landry, 2004). A negative instantaneous growth rates $\left(\mu_{0}\right)$, occurring mostly between -0.01 and 0 day $^{-1}$, was changed to +0.01 day $^{-1}$ to facilitate the calculations (Calbet \& Landry, 2004).

Four sediment samples were taken from each lake in late summer 2004 using an Ekman grab. The surface sediment from each sample was carefully transferred into a glass vial and extracted with $90 \%$ acetone. The content of chlorophyll $a$ and phaeopigments in the sediments was done using the acidification method described earlier and a Turner Design fluorometer. The dry weight of the sediment was estimated after being dried at $60^{\circ} \mathrm{C}$ for $24 \mathrm{~h}$. The overlying water samples for each sediment sample were also collected and extracted with $90 \%$ acetone to measure the content of chlorophyll $a$ and phaeopigments.

\section{Results}

Chlorophyll $a$ content of different size-

fractionated phytoplankton

The chlorophyll $a$ concentration $\left(\mu \mathrm{g}^{-1}\right)$ ranged from 6.8 to 47.4 in Lake Cataouatche, 3.6-24.2 in Lake Salvador, and 17.1-184.9 in Lac des Allemands (Table 2). The annual average chlorophyll $a$ concentration $\left(\mu \mathrm{g}^{-1}\right)$ was 10.5 in Lake Salvador, 17.6 in Lake Cataouatche, and 61.8 in Lac des Allemands. A two-way analysis of variance demonstrated that there was a significant difference in chlorophyll $a$ concentration among the three lakes $(P<0.05)$. The highest concentration was in winter, the lowest in autumn, and there was no significant difference in the chlorophyll $a$ concentration between spring and summer. Small phytoplankton were more abundant when the chlorophyll $a$ concentration was lower, and the percentage of medium and large-sized phytoplankton increased as chlorophyll $a$ concentration increased (Fig. 2). There was a significant non-linear relationship between the contribution of each size group (measured as \%) and the total chlorophyll $a$ concentration $\left(\mu \mathrm{g} \mathrm{l}^{-1}\right)$ (Fig. 2).

Microzooplankton grazing and phytoplankton growth

Rotifers are the dominant microzooplankton in southeast Louisiana brackish waters. Stone et al. (1980), for example, found 67 species of rotifers in Lake Pontchartrain and these same rotifers were also the dominant taxon in our study. The major microzooplankton found in the lakes we sampled were rotifers, such as Polyarthra sp., Branchionus sp., Keratella sp., Filinia longiseta (Ehrenberg, 1834), and ciliates. Although the raw water (screened with $202 \mu \mathrm{m}$ mesh) was used for the microzooplankton grazing experiment, it is possible that smaller ciliates $<37 \mu \mathrm{m}$ were strained from the sample because of the large mesh 


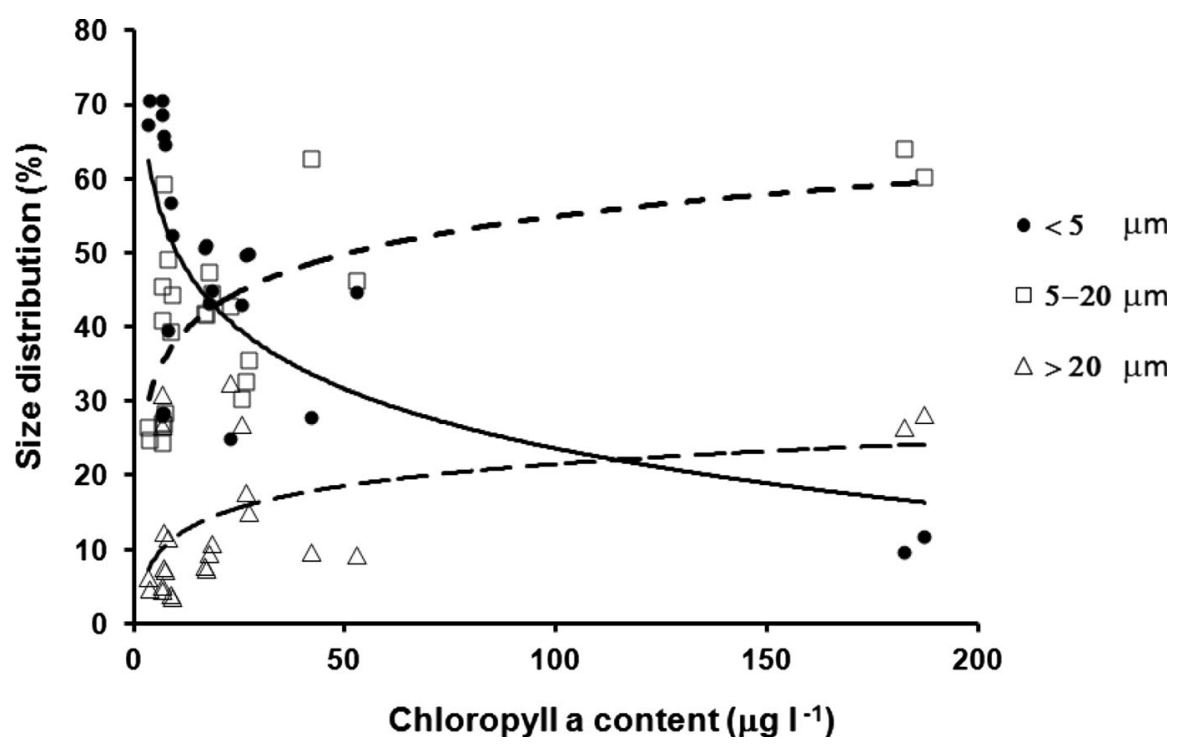

Fig. 2 Relationship between total phytoplankton chlorophyll $a$ content and percentage of size-fractionated phytoplankton; the following regressions fit the curves of phytoplankton $<5 \mu \mathrm{m}$, 5-20 $\mu \mathrm{m}$, and $>20 \mu \mathrm{m}: Y=-11.58 \ln (X)+76.94, R=0.68$,

size $(37 \mu \mathrm{m})$ used for the microzooplankton collection and quantification. An analysis of variance showed that Lac des Allemands had a higher concentration of microzooplankton than the other two lakes $(P=0.001)$, but that there was no seasonal differences in microzooplankton abundance $(P=0.75$; Table 2). Among the three lakes, the microzooplankton grazing rates were highest in Lake Salvador (Table 3), which also had the lowest chlorophyll $a$ concentration (Table 2). There was no grazing in the hypereutrophic Lac des Allemands during the winter or summer when the chlorophyll $a$ biomass was $184.9 \pm 2.5$ and $26.9 \pm 0.3 \mu \mathrm{g}^{-1}$, respectively (mean $\pm 1 \mathrm{SD}$ ). There was no significant relationship found between either microzooplankton grazing and microzooplankton abundance or between microzooplankton grazing and chlorophyll $a$ content (either by size fraction or total phytoplankton).

The instantaneous phytoplankton growth rates increased with phytoplankton size, but not significantly, while the apparent growth rate of phytoplankton $>20 \mu \mathrm{m}$ was greater than those of both the $<5 \mu \mathrm{m}$ and the 5-20 $\mu \mathrm{m}$ size fractions (Table 4). The microzooplankton grazing rate was higher on small phytoplankton and decreased when phytoplankton size increased (Table 4). The variability in grazing rates
$P<0.01 ; \quad Y=7.33 \ln (X)+21.12, \quad R=0.64, \quad P<0.01$; $Y=4.25 \ln (X)+1.93, R=0.48, P<0.05$. The $X$-axis is the total chlorophyll $a$ content $\left(\mu \mathrm{g}^{-1}\right)$; the $Y$-axis is the $\%$ of total chlorophyll within each size class

was high in all four seasons. We determined the relationship between microzooplankton grazing and phytoplankton growth and found that the proportional loss of the small, medium, and large phytoplankton, and the total phytoplankton community by microzooplankton grazing was $44,53,0$, and $29 \%$, respectively.

\section{Discussion}

Based on the chlorophyll $a$ concentrations in Lake Cataouatche, Lake Salvador, and Lac des Allemands, the trophic status of these three lakes was mostly meso- to hypereutrophic (Bricker et al., 2003). The nutrient loading to the three lakes includes loading from local runoff and atmospheric deposition. Fertilizer runoff from sugar cane cropland surrounding Lac des Allemands is a likely source of the nutrients stimulating chlorophyll $a$ accumulation. The primary nutrient source for Lake Cataouatche is from the Davis Pond Diversion, which receives water from a Mississippi River diversion. Some of this diverted water enters Lake Salvador. The Atchafalaya River is a source of some water brought to Lake Salvador via the Intracoastal Waterway, which is located on its southwestern and southeastern border. 
Table 3 Microzooplankton grazing rates on phytoplankton $\left(\right.$ day $\left.^{-1}\right)$ determined using the dilution method ( $n=24$ for each experiment) in the lakes by season

\begin{tabular}{|c|c|c|c|c|}
\hline Water body/season/phytoplankton size & Linear regression equation & $R$ & $P$ value & Grazing rate $\left(\right.$ day $\left.^{-1}\right)$ \\
\hline \multicolumn{5}{|l|}{ Lake Cataouatche } \\
\hline \multicolumn{5}{|l|}{ Autumn 2003} \\
\hline$<5 \mu \mathrm{m}$ & $y=-0.33 x+0.72$ & 0.69 & $<0.01$ & 0.33 \\
\hline $5-20 \mu \mathrm{m}$ & $*$ & & & 0.00 \\
\hline$>20 \mu \mathrm{m}$ & $*$ & & & 0.00 \\
\hline Total phytoplankton & $y=-0.07 x+0.88$ & 0.44 & $<0.01$ & 0.07 \\
\hline \multicolumn{5}{|l|}{ Winter 2004} \\
\hline$<5 \mu \mathrm{m}$ & $y=-0.57 x+0.35$ & 0.77 & $<0.01$ & 0.57 \\
\hline $5-20 \mu \mathrm{m}$ & $*$ & & & 0.00 \\
\hline$>20 \mu \mathrm{m}$ & $*$ & & & 0.00 \\
\hline Total phytoplankton & $y=-0.22 x+0.34$ & 0.84 & $<0.01$ & 0.23 \\
\hline \multicolumn{5}{|l|}{ Spring 2004} \\
\hline$<5 \mu \mathrm{m}$ & $* *$ & & & 0.23 \\
\hline $5-20 \mu \mathrm{m}$ & $* *$ & & & 0.67 \\
\hline$>20 \mu \mathrm{m}$ & $*$ & & & 0.00 \\
\hline Total phytoplankton & $*$ & & & 0.00 \\
\hline \multicolumn{5}{|l|}{ Summer 2004} \\
\hline$<5 \mu \mathrm{m}$ & $*$ & & & 0.00 \\
\hline $5-20 \mu \mathrm{m}$ & $y=-0.90 x+1.84$ & 0.84 & $<0.01$ & 0.91 \\
\hline$>20 \mu \mathrm{m}$ & $*$ & & & 0.00 \\
\hline Total phytoplankton & $* *$ & & & 0.04 \\
\hline \multicolumn{5}{|l|}{ Lake Salvador } \\
\hline \multicolumn{5}{|l|}{ Autumn 2003} \\
\hline$<5 \mu \mathrm{m}$ & $y=-0.85 x+0.85$ & 0.87 & $<0.01$ & 0.85 \\
\hline $5-20 \mu \mathrm{m}$ & $y=-0.34 x+1.02$ & 0.74 & $<0.01$ & 0.34 \\
\hline$>20 \mu \mathrm{m}$ & $y=-0.19 x+0.10$ & 0.44 & $<0.01$ & 0.19 \\
\hline Total phytoplankton & $y=-0.63 x+0.89$ & 0.89 & $<0.01$ & 0.63 \\
\hline \multicolumn{5}{|l|}{ Winter 2004} \\
\hline$<5 \mu \mathrm{m}$ & $y=-0.74 x+0.30$ & 0.84 & $<0.01$ & 0.74 \\
\hline $5-20 \mu \mathrm{m}$ & $*$ & & & 0.00 \\
\hline$>20 \mu \mathrm{m}$ & $y=-0.18 x+0.43$ & 0.55 & $<0.01$ & 0.18 \\
\hline Total phytoplankton & $y=-0.16 x+0.26$ & 0.69 & $<0.01$ & 0.16 \\
\hline \multicolumn{5}{|l|}{ Spring 2004} \\
\hline$<5 \mu \mathrm{m}$ & $y=-0.46 x+0.47$ & 0.52 & $<0.01$ & 0.46 \\
\hline $5-20 \mu \mathrm{m}$ & $*$ & & & 0.00 \\
\hline$>20 \mu \mathrm{m}$ & $y=-0.64 x+0.89$ & 0.54 & $<0.01$ & 0.64 \\
\hline Total phytoplankton & $y=-0.44 x+0.97$ & 0.85 & $<0.01$ & 0.44 \\
\hline \multicolumn{5}{|l|}{ Summer 2004} \\
\hline$<5 \mu \mathrm{m}$ & $y=-0.56 x+1.30$ & 0.95 & $<0.01$ & 0.56 \\
\hline $5-20 \mu \mathrm{m}$ & $y=-0.37 x+1.63$ & 0.81 & $<0.01$ & 0.37 \\
\hline$>20 \mu \mathrm{m}$ & $y=-0.44 x+1.39$ & 0.73 & $<0.01$ & 0.44 \\
\hline Total phytoplankton & $y=-0.47 x+1.39$ & 0.95 & $<0.01$ & 0.47 \\
\hline
\end{tabular}


Table 3 continued

\begin{tabular}{|c|c|c|c|c|}
\hline Water body/season/phytoplankton size & Linear regression equation & $R$ & $P$ value & Grazing rate $\left(\right.$ day $\left.^{-1}\right)$ \\
\hline \multicolumn{5}{|l|}{ Lac des Allemands } \\
\hline \multicolumn{5}{|l|}{ Autumn 2003} \\
\hline$<5 \mu \mathrm{m}$ & $y=-0.18 x+0.74$ & 0.49 & $<0.01$ & 0.18 \\
\hline $5-20 \mu \mathrm{m}$ & $y=-0.36 x+0.85$ & 0.85 & $<0.01$ & 0.36 \\
\hline$>20 \mu \mathrm{m}$ & $y=-0.37 x+0.73$ & 0.54 & $<0.01$ & 0.37 \\
\hline Total phytoplankton & $y=-0.23 x+0.75$ & 0.87 & $<0.01$ & 0.23 \\
\hline \multicolumn{5}{|l|}{ Winter 2004} \\
\hline$<5 \mu \mathrm{m}$ & $*$ & & & 0.00 \\
\hline $5-20 \mu \mathrm{m}$ & $*$ & & & 0.00 \\
\hline$>20 \mu \mathrm{m}$ & $*$ & & & 0.00 \\
\hline Total phytoplankton & $*$ & & & 0.00 \\
\hline \multicolumn{5}{|l|}{ Spring 2004} \\
\hline$<5 \mu \mathrm{m}$ & $y=-0.31 x+0.15$ & 0.84 & $<0.01$ & 0.31 \\
\hline $5-20 \mu \mathrm{m}$ & $*$ & & & 0.00 \\
\hline$>20 \mu \mathrm{m}$ & $*$ & & & 0.00 \\
\hline Total phytoplankton & $y=-0.14 x+0.12$ & 0.75 & $<0.01$ & 0.14 \\
\hline \multicolumn{5}{|l|}{ Summer 2004} \\
\hline$<5 \mu \mathrm{m}$ & $*$ & & & 0.00 \\
\hline $5-20 \mu \mathrm{m}$ & $*$ & & & 0.00 \\
\hline$>20 \mu \mathrm{m}$ & $*$ & & & 0.00 \\
\hline Total phytoplankton & $*$ & & & 0.00 \\
\hline
\end{tabular}

* No grazing impact was found

** Grazing saturation was found

Table 4 Average microzooplankton grazing $(n=12)$ and phytoplankton growth rate $(n=48)$ in the upper Barataria estuary (mean $\pm 1 \mathrm{SE})$

\begin{tabular}{llll}
\hline $\begin{array}{l}\text { Phytoplankton } \\
\text { size }\end{array}$ & $\begin{array}{l}\text { Microzooplankton grazing rate, } \\
m\left(\mathrm{day}^{-1}\right)\end{array}$ & $\begin{array}{l}\text { Phytoplankton instantaneous growth } \\
\text { rate, } \mu_{0}\left(\mathrm{day}^{-1}\right)\end{array}$ & $\begin{array}{l}\text { Phytoplankton apparent growth rate, } \\
k_{0}\left(\mathrm{day}^{-1}\right)\end{array}$ \\
\hline$<5 \mu \mathrm{m}$ & $0.35 \pm 0.09$ & $0.17 \pm 0.06$ & $-0.24 \pm 0.06^{\mathrm{a}}$ \\
$>5$ to $<20 \mu \mathrm{m}$ & $0.22 \pm 0.09$ & $0.28 \pm 0.06$ & $0.06 \pm 0.05^{\mathrm{a}}$ \\
$>20 \mu \mathrm{m}$ & $0.15 \pm 0.07$ & $0.33 \pm 0.06$ & $0.21 \pm 0.06^{\mathrm{b}}$ \\
$\begin{array}{l}\text { Total } \\
\text { phytoplankton }\end{array}$ & $0.20 \pm 0.06$ & $0.26 \pm 0.03$ & $0.01 \pm 0.04$ \\
\hline
\end{tabular}

Data with different letters in the same column means that there are significant differences (ANOVA, $P<0.05$ )

The growth data indicate that large phytoplankton outpace the growth of small phytoplankton in these eutrophic waters. As a result, the total phytoplankton chlorophyll $a$ content increased as the percentage of small phytoplankton $(<5 \mu \mathrm{m})$ decreased logarithmically, while the percentage of large phytoplankton
$(>20 \mu \mathrm{m})$ and medium phytoplankton $(5<20 \mu \mathrm{m})$ increased logarithmically. These results are consistent with the observation that long-chain diatoms and colonial cyanobacterial blooms occur on a regular basis in these lakes (Rabalais, 2005). Others have also reported that there is a tendency toward replacement of 
small taxa by large taxa as phytoplankton biomass increases, or a tendency toward an increased size of particular taxa (Duarte et al., 1990; Duarte \& Canfield, 1992). The causes of these size distributions could be the result of micro- or mesoplankton grazing, benthic filter-feeders, size-selective sedimentation, or different photosynthesis rates of different size classes of phytoplankton (Cermeño et al., 2005).

The microzooplankton community in these lakes is composed mainly of planktonic rotifers (42-202 $\mu \mathrm{m}$ ), copepod nauplii, and a few ciliates. Hansen et al. (1997) summarized the size selectivity spectra of multiple individual zooplankton predators collected from feeding studies and concluded that the linear size ratio between the suspension filter-feeding rotifers and their optimal prey is $18: 1$. We used this ratio and determined that the optimum size for rotifer prey would be between 2.3 and $11.2 \mu \mathrm{m}$, which is in the size range of the phytoplankton group mostly impacted by microzooplankton grazing demonstrated in our present study. Although the data used by Hansen et al. (1997) were mostly collected using laboratory cultured zooplankton predators and preys (microalgae), our experiment using the undivided microzooplankton community provides solid evidence that microzooplankton grazing on phytoplankton is sizedependent. Cermeño et al. (2005) discovered that the higher photochemical efficiency of phytoplankton $>20 \mu \mathrm{m}$ is a key reason why large phytoplankton are dominant in eutrophic waters. The present research demonstrates that the stronger top-down control on smaller phytoplankton, but weaker impact on larger phytoplankton by microzooplankton community grazing, could also be a possible mechanism explaining why small phytoplankton become less abundant than large phytoplankton in eutrophic/hypereutrophic waters. The data interpretation seems appropriate for the range of chlorophyll $a$ values examined (annual average from 10.5 to $61.8 \mu \mathrm{g}$ chlorophyll $a \mathrm{l}^{-1}$ ), but may not be appropriate for situations with lower chlorophyll $a$ concentrations, in colder climates, or in situations with different turbidity levels, etc.

An average of 67 and $60 \%$ of the phytoplankton growth in marine and coastal systems, respectively, is controlled by microzooplankton grazing (Calbet \& Landry, 2004). The grazing on the total phytoplankton in our present experiment is less than half of these rates (Table 4). Phytoplankton cells generally decrease in size from inshore to offshore (Mouw \& Yoder, 2005), and the phytoplankton in the open ocean are usually consist of picophytoplankton that dominate chlorophyll biomass (Odate, 1996). Because small phytoplankton in Lake Salvador are more dominant than in Lake Cataouatche or Lac des Allemands, the impact of grazing from microzooplankton in Lake Salvador was more significant than in the other two lakes. The majority of phytoplankton in Lake Cataouatche and Salvador were diatoms at most times, while cyanobacteria were the dominant group with $56 \%$ in autumn 2003 and up to $96 \%$ in other seasons (Ren et al., 2009). This difference may also partially explain the limited effect of microzooplankton grazing in Lac des Allemands, especially in winter, spring, and summer, because cyanobacteria are usually not preferred food items by many zooplankton groups such as rotifers (Sellner et al., 1993). Nonetheless, our study provides direct evidence that, in these eutrophic waters, microzooplankton grazing provides little top-down control of phytoplankton growth, and almost no control on the largest phytoplankton (Table 4). According to Cermeño et al. (2005), large phytoplankton have a higher maximum photosynthetic efficiency among different size-fractionated phytoplankton. In addition, because smaller microzooplankton such as flagellates and small ciliates $(<37 \mu \mathrm{m})$ were not quantified in the study, the role of these grazers should be evaluated in these eutrophic waters in the future (Nejstgaard et al., 2001).

The mesozooplankton in the three lakes we studied was composed mainly by Acartia tonsa Dana, 1849, Eurytemora affinis (Poppe, 1880), Dalphnia lumholtzi G.O. Sars, 1885, large rotifers $(>202 \mu \mathrm{m})$, and large copepod nauplii $(>202 \mu \mathrm{m})$. However, two experiments on mesozooplantkon grazing conducted in summer 2005 did not show a significant impact on

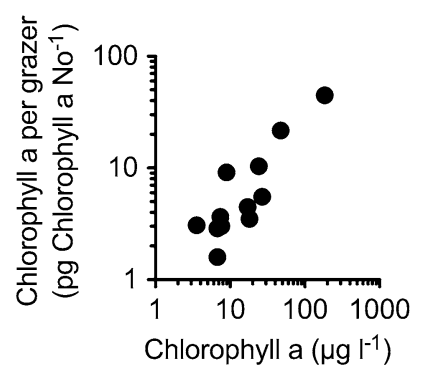

Fig. 3 The relationship between the amount of chlorophyll $a$ per microzooplankton (pg chlorophyll $a \mathrm{no}^{-1}$ ) in all three lakes. The data are from Table 2 


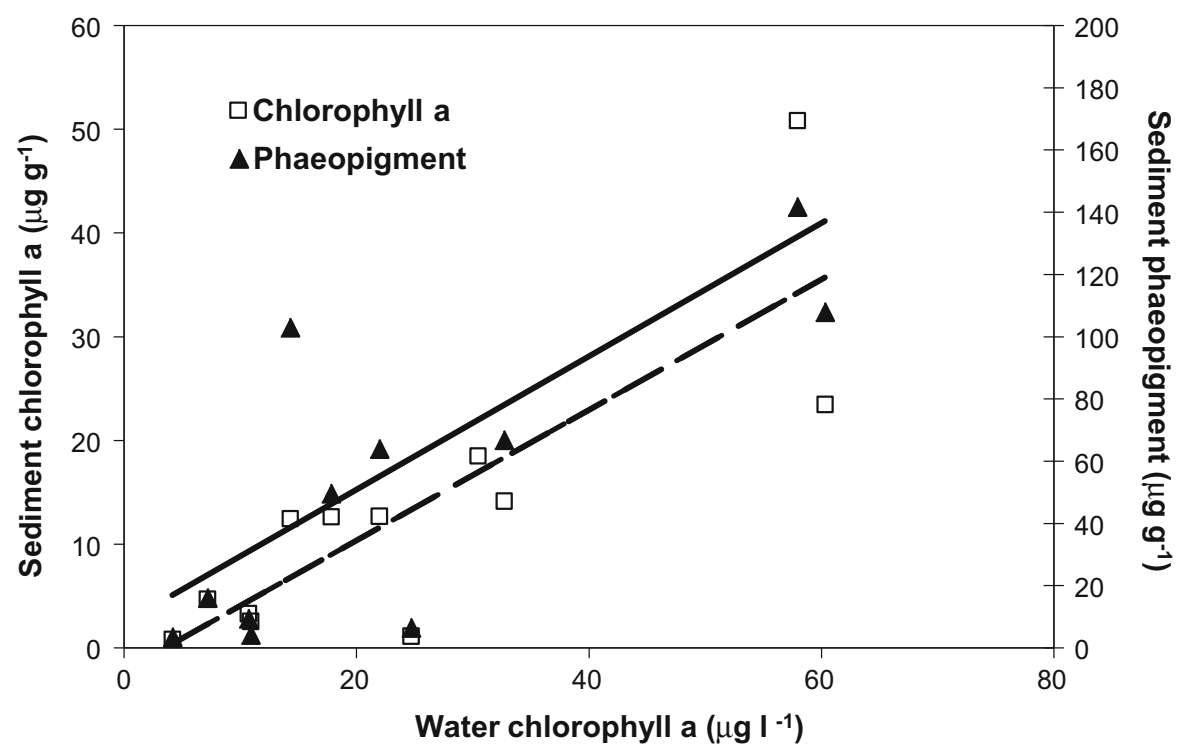

Fig. 4 Relationship between water chlorophyll $a$ content and sediment chlorophyll a (open symbols) and phaeopigment content (dark symbols) (microgram per gram dry weight of sediment) in Lac des Allemands, Lake Salvador, and Lake

phytoplankton growth in Lake Salvador and Lac des Allemands (Wong et al., unpublished data). The density of zooplankton did not increase in proportion to the rise in chlorophyll $a$ biomass (Fig. 3) although mesozooplankton were present in these waters, and were sometimes even abundant. This result suggests that mesoplankton were unable to compensate for higher phytoplankton growth of larger phytoplankton in the upper Barataria estuary and is consistent with what is reported in the scientific literature. For example, it appears that mesozooplankton have a minimal role in controlling total phytoplankton biomass in highly productive estuarine and coastal areas (Strom et al., 2001; Calbet et al., 2003; Chan et al., 2004; Lionard et al., 2005) and there is a decline of relative importance of mesozooplankton grazing with increasing primary production in marine ecosystems, and the effect of mesozooplankton on primary production (\% consumed per day) is moderate in most of the studies (Calbet, 2001). Alternative food sources (e.g., protozoans) could represent an important component of mesozooplankton diet in unproductive ecosystems (Calbet, 2001).

Zooplankton, therefore, appear to have a limited impact on phytoplankton growth (i.e., limited impact on small phytoplankton from microzooplankton from
Cataouatche. The regression line (dotted line) for chlorophyll $a$ is $Y=0.63 X-2.24(n=12, R=0.83, P<0.001)$ and the regression line (solid) for phaeopigments is $Y=2.14 X+8.04$ $(n=12, R=0.72, P<0.005)$

the present study and no effect on phytoplankton from preliminary mesozooplankton grazing study) in these lakes, and they appear to be unable to control phytoplankton there.

The other phytoplankton grazers in this system include benthic suspension feeders, such as Rangia clams or multiple species of freshwater sponges, that may impede the development of microalgae blooms because of their relatively high filtration rates (Buskey et al., 1997, Murrell \& Hollibaugh, 1998, Abadie \& Poirrier, 2000; Bologna et al., 2005; Wong et al., 2010). Losses by advection of phytoplankton biomass from these coastal lakes are minimal because there are no strong currents and water residence times are high (pers. comm., E. Swenson). Sinking may be the fate for most of the phytoplankton in these three lakes. Support for this possibility is provided by the strong relationship between the chlorophyll $a$ biomass in overlying waters and the sediment chlorophyll $a$ and phaeopigment concentrations in each lake in summer 2004 (Fig. 4). These experimental lakes are turbid (high chlorophyll $a$ concentrations in Table 2), e.g., it is not possible to see the bottom of these shallow lakes $(<2.5 \mathrm{~m})$. Benthic microalgal growth in these lakes should be limited by light because the secchi disk is $<1 \mathrm{~m}$ (Ren et al., 2009). 
The relative weakness of microzooplankton topdown grazing control on the largest phytoplankton, and the relatively fast growth of large phytoplankton observed in our experiments, may be why the average size of phytoplankton tends to increase when phytoplankton become more abundant in these meso- and hypereutrophic waters, and elsewhere. Size-selective grazing of predators on prey may also drives changes in the algal size structure of oligotrophic waters, which is something to quantify with additional research, and result in quite different outcomes, or not.

\section{Conclusions}

We found that microzooplankton grazing rates on small phytoplankton $(<5 \mu \mathrm{m})$ were higher than on the large phytoplankton $(>20 \mu \mathrm{m})$ in these eutrophic waters. The proportional loss of the small, medium, large phytoplankton, and total phytoplankton community by microzooplankton grazing was $44,53,0$, and $29 \%$, respectively. The grazing impacts of microzooplankton on phytoplankton in eutrophic waters are size specific. The relatively strong control on smaller phytoplankton and weakness of top-down grazing control on large phytoplankton by microzooplankton, as well as the relatively fast growth of large phytoplankton, may explain why the average size of phytoplankton, whether as isolated cells or as colonies, tends to increase in eutrophic waters.

Acknowledgments The work was supported by the National Oceanic and Atmospheric Administration, Center for Sponsored Coastal Ocean Research, Grants Nos. NA16OP2670 to LSU and NA16OP2671 to LUMCON. We thank A. Sapp, K. Reynolds, W. Morrison, and L. Ren for their field assistance. We thank H. B. Liu for helpful comments on the experimental design.

\section{References}

Abadie, S. W. \& M. A. Poirrier, 2000. Increased density of large Rangia clams in Lake Pontchartrain after the cessation of shell dredging. Journal of Shellfish Research 19: 481-485.

Bologna, P. A. X., M. L. Fetzer, S. Mcdonnell \& E. M. Moody, 2005. Assessing the potential benthic-pelagic coupling in episodic blue mussel (Mytilus edulis) settlement events within eelgrass (Zostera marina) communities. Journal of Experimental Marine Biology and Ecology 316: 117-131.

Bricker, S. B., J. G. Ferreira \& T. Simas, 2003. An integrated methodology for assessment of estuarine trophic status. Ecological Modelling 169: 39-60.
Bulit, C., C. Diaz-Avalos, M. Signoret \& D. J. S. Montagnes, 2003. Spatial structure of planktonic ciliate patches in a tropical coastal lagoon: an application of geostatistical methods. Aquatic Microbial Ecology 30: 185-196.

Buskey, E. J., P. A. Montagna, A. F. Amos \& T. E. Whitledge, 1997. Disruption of grazer populations as a contributing factor to the initiation of the Texas brown tide algal bloom. Limnology and Oceanography 42: 1215-1222.

Calbet, A., 2001. Mesozooplankton grazing effect on primary production: a global comparative analysis in marine ecosystems. Limnology and Oceanography 46: 1824-1830.

Calbet, A. \& M. R. Landry, 2004. Phytoplankton growth, microzooplankton grazing, and carbon cycling in marine systems. Limnology and Oceanography 49: 51-57.

Calbet, A., J. Felipe, M. Vila, M. M. Sala, M. Alcaraz \& M. Estrada, 2003. Relative grazing impact of microzooplankton and mesozooplankton on a bloom of the toxic dinoflagellate Alexandrium minutum. Marine Ecology Progress Series 259: 303-309.

Carrick, H. J. \& C. L. Schelske, 1997. Have we overlooked the importance of small phytoplankton in productive waters? Limnology and Oceanography 42: 1613-1621.

Cermeño, P., P. Estévez-Blanco, E. Marañón \& E. Fernández, 2005. Maximum photosynthetic efficiency of size-fractionated phytoplankton assessed by ${ }^{14} \mathrm{C}$ uptake and fast repetition rate fluorometry. Limnology and Oceanography 50: $1438-1446$.

Chan, F., M. L. Pace, R. W. Howarth \& R. M. Marino, 2004. Bloom formation in heterocystic nitrogen-fixing cyanobacteria: the dependence on colony size and zooplankton grazing. Limnology and Oceanography 49: 2171-2178.

Chisholm, S. W., 1992. Phytoplankton size. In Falkowski, P. G. \& A. D. Woodhead (eds), Primary Productivity and Biogeochemical Cycles in the Sea. Plenum, New York: 213-237.

Duarte, C. M. \& D. E. Canfield, 1992. Patterns in phytoplankton community structure in Florida lakes. Limnology and Oceanography 37: 155-161.

Duarte, C. M., S. Agusti \& D. E. Canfield, 1990. Size plasticity of freshwater phytoplankton: implications for community structure. Limnology and Oceanography 35: 1846-1851.

Fenchel, T., 1982. Ecology of heterotrophic microflagellates. 4. Quantitative occurrence and importance as bacterial consumers. Marine Ecology Progress Series 9: 35-42.

Gallegos, C. L., 1989. Microzooplankton grazing on phytoplankton in the Rhode River, Maryland: nonlinear feeding kinetics. Marine Ecology Progress Series 57: 23-33.

Garza-Mourino, G., M. Silva-Briano, S. Nandini, S. S. S. Sarma \& M. E. Castellanos-Paez, 2005. Morphological and morphometrical variations of selected rotifer species in response to predation: a seasonal study of selected brachionid species from Lake Xochimilco (Mexico). Hydrobiologia 546: 169-179.

Gin, K. Y. H., X. Lin \& S. Zhang, 2000. Dynamics and size structure of phytoplankton in the coastal waters of Singapore. Journal of Plankton Research 22: 1465-1484.

Goldman, J. C. \& D. A. Caron, 1985. Experimental studies on an omnivorous microflagellate: implications for grazing and nutrient regeneration in the marine microbial food chain. Deep Sea Research 32: 899-915. 
Haga, H., T. Nagata \& M. Sakamoto, 1995. Size-fractionated $\mathrm{NH},+$ regeneration in the pelagic environments of two mesotrophic lakes. Limnology and Oceanography 40: 1091-1099.

Hansen, P. J., P. K. Bjornsen \& B. W. Hansen, 1997. Zooplankton grazing and growth: scaling within the 2-2,000$\mu \mathrm{m}$ body size range. Limnology and Oceanography 42 : 687-704.

Harris, G. P., 1986. Phytoplankton Ecology: Structure, Function and Fluctuation. Chapman and Hall, New York.

Landry, M. R. \& R. P. Hassett, 1982. Estimating the grazing impact of marine microzooplankton. Marine Biology 67: 283-288.

Landry, M. R., S. L. Brown \& L. Campbell, 1998. Spatial patterns in phytoplankton growth and microzooplankton grazing in the Arabian Sea during monsoon forcing. Deep Sea Research II 45: 2353-2368.

Legendre, L., M. Gosselin, H. J. Hirche, G. Kattner \& G. Rosenberg, 1993. Environmental control and potential fate of size-fractionated phytoplankton production in the Greenland Sea (75 degrees-N). Marine Ecology Progress Series 98: 297-313.

Lionard, M., F. Azemar, S. Bouletreau, K. Muylaert, M. Tackx \& W. Vyverman, 2005. Grazing by meso- and microzooplankton on phytoplankton in the upper reaches of the Schelde estuary (Belgium/The Netherlands). Estuarine, Coastal and Shelf Science 64: 764-774.

Liu, H. \& M. J. Dagg, 2003. Interactions between nutrients, phytoplankton growth, and micro- and mesozooplankton grazing in the plume of the Mississippi River. Marine Ecology Progress Series 258: 31-42.

Liu, X., C. H. Tang \& C. K. Wong, 2014. Microzooplankton grazing and selective feeding during bloom periods in the Tolo Harbour area as revealed by HPLC pigment analysis. Journal of Sea research 90: 83-94.

Mouw, C. B. \& J. A. Yoder, 2005. Primary production calculations in the Mid-Atlantic Bight, including effects of phytoplankton community size structure. Limnology and Oceanography 50: 1232-1243.

Murrell, M. C. \& J. T. Hollibaugh, 1998. Microzooplankton grazing in northern San Francisco Bay measured by the dilution method. Aquatic Microbial Ecology 15: 53-63.

Nejstgaard, J. C., L.-J. Naustvoll \& A. Sazhin, 2001. Correcting for underestimation of microzooplankton grazing in bottle incubation experiments with mesozooplankton. Marine Ecology Progress Series 221: 59-75.

Odate, T., 1996. Abundance and size composition of the summer phytoplankton community structure in the northern North Pacific Ocean, the Bering Sea, and the Gulf of Alaska. Journal of Oceanography 52: 335-351.

Pagano, M. \& L. Saintjean, 1989. Comparison of 2 techniques for sampling zooplankton, the net and the schindler trap, tested at Ebrie Lagoon (Ivory coast). Hydrobiologia 173: 167-172.

Rabalais, N. N., 2005. Consequences of Mississippi River diversions for Louisiana coastal restoration. National Wetlands Newsletter 27: 21-24.

Raven, J. A., 1998. The twelfth Tansley lecture. Small is beautiful: the picophytoplankton. Functional Ecology 12: 503-513.

Redden, A., B. Sanderson \& D. Rissik, 2002. Extending the analysis of the dilution method to obtain the phytoplankton concentration at which microzooplankton grazing becomes saturated. Marine Ecology Progress Series 226: 27-33.

Ren, L., N. N. Rabalais, R. E. Turner, W. Morrison \& W. Mendenhall, 2009. Nutrient limitation on phytoplankton growth in the Upper Barataria Basin, Louisiana: microcosm bioassays. Estuaries and Coasts 32: 958-974.

Sellner, K. G., D. C. Brownlee, M. H. Bundy, S. G. Brownlee \& K. R. Braun, 1993. Zooplankton grazing in a Potomac River cyanobacteria bloom. Estuaries 16: 859-872.

Sherr, B. F. \& E. B. Sherr, 1984. Role of heterotrophic protozoa in carbon and energy flow in aquatic ecosystems. In Klug, M. J. \& C. A. Reddy (eds), Current Perspectives in Microbial Ecology. American Society for Microbiology, Washington, DC: 412-423.

Stone, J. H., N. A. Drummond, L. L. Cook, E. C. Theriot \& D. M. Lindstedt, 1980. The distribution and abundance of plankton of Lake Pontchartrain, Louisiana, 1978. In Stone, J. H. (ed.), Environmental Analysis of Lake Pontchartrain, Louisiana, Its Surrounding Wetlands, and Selected Land Uses. Coastal Ecology Laboratory, Center For Wetland Resources, Louisiana State University, Baton Rouge: 437-591.

Strom, S. L., M. A. Brainard, J. L. Holmes \& M. B. Olson, 2001. Phytoplankton blooms are strongly impacted by microzooplankton grazing in coastal North Pacific waters. Marine Biology 138: 355-368.

Tamigneaux, E., L. Legendre, B. Klein \& M. Mingelbier, 1999. Seasonal dynamics and potential fate of size-fractionated phytoplankton in a temperate nearshore environment (Western Gulf of St Lawrence, Canada). Estuarine Coastal Shelf Science 48: 253-269.

Thatcher, S. J., C. C. Davis \& G. A. Gardner, 1993. Physical and chemical effects of macrograzers and micrograzers on enclosed, in situ phytoplankton in a Nefoundland Lake. Hydrobiologia 250: 127-141.

Watson, S. \& J. Kalff, 1981. Relationships between nannoplankton and lake trophic status. Canadian Journal of Fisheries and Aquatic Sciences 38: 960-967.

Wong, W. H., N. N. Rabalais \& R. E. Turner, 2010. Ecological significance of the clam Rangia cuneata (woersby, 1831) in upper Barataria estuary, Louisiana. Hydrobiologia 651: 305-315. 